\title{
Chosen Blindness or a Revelation of the Truth?
}

\author{
A New Procedure for Revision in Belgium
}

\author{
Katrien Verhesschen \& Cyrille Fijnaut*
}

\begin{abstract}
The Belgian Code of criminal procedure provides the possibility to revise final criminal convictions. This procedure had remained more or less untouched for 124 years, but was finally reformed by the Act of 2018, after criticism was voiced in legal doctrine concerning its narrow scope and possible appearances of partiality and prejudice. The Act of 2018 therefore broadened the third ground for revision, the so-called novum, and defined it as an element that was unknown to the judge during the initial proceedings and impossible for the convicted person to demonstrate at that time and that, alone or combined with evidence that was gathered earlier, seems incompatible with the conviction, thus creating a strong suspicion that, if it had been known, it would have led to a more favourable outcome. Thereby, this ground for revision is no longer limited to factual circumstances, but also includes changed appreciations by experts. To counter appearances of partiality and prejudice, the Act of 2018 created the Commission for revision in criminal matters, a multidisciplinary body that has to give non-binding advice to the Court of Cassation on the presence of a novum. However, the legislature also introduced new hurdles on the path to revision, such as the requirement for the applicant to add pieces that demonstrate the ground for revision in order for his or her request to be admissible. For that reason, the application in practice will have to demonstrate whether the Act of 2018 made the revision procedure more accessible in reality.
\end{abstract}

Keywords: final criminal conviction, revision procedure, grounds for revision, Court of Cassation, Commission for revision in criminal matters

\section{Introduction}

The Belgian 'Wetboek van strafvordering', 'Code d'instruction criminelle' (Code of criminal procedure; hereinafter: CCP) provides the possibility to revise final criminal convictions in Article 443 et seq. In contrast to its surrounding states, Belgium has not been confronted

Katrien Verhesschen is a PhD candidate and teaching assistant at the Institute of Criminal Law KU Leuven. Cyrille Fijnaut is Emeritus Professor of Criminal Law \& Criminology at Erasmus University Rotterdam, KU Leuven and Tilburg University. yet with notorious, highly publicised wrongful convictions that led to a thorough evaluation of this procedure. Although there have been cases in which convicted persons insisted on their innocence and were supported in their claim by journalists, ${ }^{1}$ this never resulted in a broad public debate about widening the possibility to re-examine final criminal convictions. It would be naive, however, to think this means that there are no wrongful convictions in Belgium. Although hard to measure, it is more likely a symptom of the procedure being very strict. $^{2}$

Despite the lack of public pressure, the revision procedure was criticised in legal doctrine for its narrow scope. ${ }^{3}$ The impression was that the procedure strongly preferred legal certainty and the authority of res iudicata, giving truth and justice barely a chance to surface. Because the procedure was so cumbersome, it was hard to get a wrongful conviction recognised as such. ${ }^{4}$ Although legal doctrine had to shout hard and long, its criticism was picked up by the legislature. With the Act of $2018,{ }^{5}$ it finally reformed the procedure for revision, which had remained more or less untouched for 124

1. See, for example, D. De Coninck, 14 jaar onschuldig in een Belgische gevangenis - De Gebroeders Gottschalk (2014); F. Meert and W. Van Den Eynde, De bloedkamer (2011). The former book criticises the revision procedure for the narrow scope of the grounds for revision and the possibly long duration of the procedure. The latter book does not elaborate on the revision procedure but only mentions that a request for revision was filed. Yet critics of the (former) revision procedure often invoke the case of Mr Meert. One of the reasons is that, in this case, the request for revision was referred by the Court of Cassation for advice to (the civil chamber of) the court of appeal of Antwerp, while the original conviction had been rendered by the court of appeal of Antwerp as well (albeit by its criminal chamber) (see infra footnote 59). This created an appearance of prejudice and partiality.

2. D. Leestmans, 'Dwalingen rechtzetten schept vertrouwen in ons rechtssysteem', 292 Juristenkrant 10 (2014), at 10 (hereinafter: Leestmans); Ph. Traest and J. Roelandt, 'Herziening van de herziening anno 2019', 6 Nullum Crimen 481, at 481 (2019) (hereinafter: Traest a.o. (2019)).

3. See, among others, $M$. Colette, 'Filip Meert en de herziening in strafzaken: het moet anders', 258 Juristenkrant 13 (2012) (hereinafter: Colette); Ph. Traest, 'Is de herziening in strafzaken aan herziening toe?', in F. Deruyck, E. Goethals, L. Huybrechts, J.-F. Leclercq, J. Rozie, M. Rozie, Ph. Traest \& R. Verstraeten (eds.), Amicus Curiae. Liber amicorum Marc De Swaef (2013) 383 (hereinafter: Traest (2013)).

4. Traest (2013), above n. 3, 383-4.

5. Wet 11 juli 2018 houdende diverse bepalingen in strafzaken - loi 11 juillet 2018 portant des diverses dispositions en matière pénale, Belgisch Staatsblad - Moniteur belge 18 July 2018, 57582. 
years. ${ }^{6}$ The Act aims to widen one of the grounds for revision and introduces a Commission for revision in criminal matters, which includes non-judges and will be involved in the examination of requests for revision. The new revision procedure entered into force on 1 March 2019. ${ }^{7}$ However, it took more than an additional year to fully implement all aspects of the new procedure. $^{8}$

In this article, we first provide an overview of the legal framework of the revision procedure. In order to give a proper understanding of the current procedure, we discuss some aspects of the former procedure as well and of the criticism voiced against it in legal doctrine. We then look at the revision procedure in practice. However, since the new revision procedure entered into force very recently, there is not much practice to turn to yet, making it hard at this stage to assess the practical impact of the reform. Instead, we look at the practice of the former revision procedure and highlight the challenges the new procedure will have to overcome. We conclude with an overview of our findings to answer the question whether the new revision procedure tackles the issues with which its predecessor struggled and which aspects of the new procedure that are currently still unclear are decisive for this.

\section{Legal Framework of the Revision Procedure}

\subsection{The Start of the Revision Procedure}

\subsubsection{Possible Applicants}

Like France, Belgium distinguishes between three categories of criminal offences. The first category comprises the most serious offences, called 'misdaad', 'crime' (felony, crime). The second comprises what are called 'wanbedrijf', 'délit' (ordinary offence, misdemeanour). The third category comprises the least serious offences, called 'overtreding', 'contravention' (contravention) (Art. 1 Strafwetboek, Code pénal). Only criminal decisions in cases concerning the two most serious categories of offences ('misdaad', 'crime' and 'wanbedrijf', 'délit') are eligible for revision (Art. 443 CCP). ${ }^{9}$ Convic-

6. Although there have been minor adjustments in the meantime, the last major reform of the revision procedure dates back to an Act of 1894 (wet 18 juni 1894 inhoudende de IXde titel van het Ille boek van het Wetboek van rechtspleging in strafzaken - loi 18 juin 1894 contenant le titre IX du livre III du Code de procédure pénale, Belgisch Staatsblad Moniteur belge 24 June 1894, 1959).

7. Art. 81 of the Act of 2018

8. Notably, the appointment of the members of the newly introduced Commission for revision in criminal matters (see infra).

9. M. Mahieu and J. van Meerbeeck, 'Procédure de révision en matière pénale', 24 DPPP 51, at 58 (2010) (hereinafter: Mahieu a.o.); Traest (2013), above n. 3, at 384

10. Each of the three categories of offences is linked to a different category of penalties. The least serious category of offences ('overtreding', 'contravention') is punished by so-called police penalties ('politiestraf', 'peine de police') (Art. 1 Strafwetboek, Code pénal). tions imposing a so-called police penalty ${ }^{10}$ are thus excluded. ${ }^{11}$

The criminal decision has to contain a finding of guilt. In Belgium there is no revision in defavorem, ${ }^{12}$ so final acquittals cannot be revised. ${ }^{13}$ Yet the actual imposition of a penalty is no longer required. The 'Hof van Cassatie', 'Cour de cassation' (Supreme Court, hereinafter: Court of Cassation) changed its case law and decided that criminal decisions in which there was a simple finding of guilt are also eligible for revision. ${ }^{14}$ Moreover, the decision has to be final. No other remedies may be available, either because they have been exhausted or because the term in which to do so has expired. ${ }^{15}$

As mentioned previously, convictions imposing a police penalty are excluded from the scope of the revision procedure. The legislature thought these penalties were of little importance, because of their short duration or limited amount. ${ }^{16}$ It stated that it would therefore not be of any inconvenience to exclude these convictions from the scope of the revision procedure. ${ }^{17}$ Some legal scholars, however, question this exclusion, especially now that a simple finding of guilt is eligible for revision. ${ }^{18}$ As a consequence, for example, a person found guilty of a 'wanbedrijf', 'délit' who did not receive a penalty, can file a request for revision, while a person sentenced to imprisonment for seven days cannot. Yet even these 'minor' convictions can have a serious impact on the convicted person's private and professional life. ${ }^{19},{ }^{20}$ Moreover, some scholars argue that it should be a point of honour for the judiciary to correct all its mistakes. ${ }^{21}$ However, for now, the more practical considerations for excluding these 'minor' convictions seem to have maintained the upper hand, since the reform of 2018 did not

11. Mahieu a.o., above n. 9, at 68-9; Traest (2013), above n. 3, at 384; Traest a.o. (2019), above n. 2, at 482-3.

12. During the parliamentary debate in the preparation of the Act of 2018 , a member of the Bar Association for the French- and German-speaking lawyers in Belgium (Ordre des Barreaux Francophones et Germanophone de Belgique) suggested the introduction of the possibility to revise final acquittals. This suggestion was not adopted. (Verslag van de eerste lezing van het wetsontwerp houdende diverse bepalingen in strafzaken - Rapport de la première lecture du projet de loi portant des dispositions diverses en matière pénale, Parl.St. Kamer - Doc.Parl. Chambre 2017-18, n. 54 2969/003, at 54 (hereinafter: Report first reading).)

13. Traest (2013), above n. 3, at 384; Traest a.o. (2019), above n. 2, at 483.

14. Court of Cassation 29 April 2009, P.08.1648.F; Mahieu a.o., above n. 9, at 59-61; Traest (2013), above n. 3, at 384-5; Traest a.o. (2019), above n. 2, at 483 .

15. Mahieu a.o., above n. 9, at 67-8

16. Currently, police penalties can amount to an imprisonment of no more than seven days and to a fine of a maximum of twenty-five euros, multiplied by the legal surcharges (Art. 28 and 38 Strafwetboek, Code pénal).

17. Exposé des motifs du projet de loi portant la troisième livre du Code de procédure pénale, Parl.St. Kamer-Doc.Parl. Chambre 1878-79, n. 15 238 , at 70.

18. Traest (2013), above n. 3 , at 385

19. Mahieu a.o., above n. 9 , at 68

20. It is interesting to note that convictions imposing a police penalty are, in principle, automatically erased from the convicted person's criminal record after three years (Art. 619 CCP), thus potentially limiting in time the impact on his or her reputation and professional life.

21. Mahieu a.o., above n. 9, at 68 
add convictions imposing a police penalty to the scope of the revision procedure. ${ }^{22}$

The convicted person can file a request for revision. If he is deceased or declared incapable or missing, a request can be filed by his spouse, descendants, ancestors, brothers and sisters. Both types of applicants cannot do so on their own. They are obliged to consult a lawyer who has to be registered at the Bar of Lawyers at the Court of Cassation. That lawyer has to sign the request, and if he does not, the request is inadmissible (Art. 444 CCP). This obligation is intended to discourage requests that have no prospect of success. ${ }^{23}$

Revision serves not only private interests, but the public interest as well. Admitting and correcting mistakes restores people's confidence in the justice system. Moreover, it allows the search for the real culprit to continue. Revision is thus in the interest of society too. ${ }^{24}$ Therefore, it can also be requested by the attorney general at the Court of Cassation and the attorneys general at the courts of appeal (Art. 444 CCP). Before the Act of 2018, the Minister for Justice was competent to request this, just as in France. However, because the Belgian legislature wanted to ensure the separation of powers and guarantee the independence of the judiciary, ${ }^{25}$ the Act of 2018 removed this competence and, following the suggestion $^{26}$ of the High Council of Justice, ${ }^{27}$ reassigned it to the aforementioned attorneys general.

\subsubsection{The Grounds for Revision}

There are three possible grounds for revision. ${ }^{28}$ The Act of 2018 has modified the third ground, in an attempt to broaden it. ${ }^{29}$ The three grounds are the following (Art. 443 CCP):

1. two (or more) distinct convictions that find different defendants guilty of the same fact and that are irrec-

22. In the explanatory memorandum, the inclusion or exclusion from convictions imposing a police penalty is not even discussed. (Memorie van toelichting bij het wetsontwerp houdende diverse bepalingen in strafzaken - Exposé des motifs du projet de loi portant des dispositions diverses en matière pénale, Parl.St. Kamer - Doc.Parl. Chambre 2017-18, n. 54 2969/001, hereinafter: Explanatory memorandum).)

23. Mahieu a.o., above n. 9, at 103.

24. Hoge Raad voor de Justitie - Conseil supérieur de la Justice, 'Advies over de ontwerptekst van wet inzake de hervorming van de herziening in strafzaken' - 'Avis sur le projet de texte de loi relatif à la réforme de la révision en matière pénale', Working Paper 2017, at 6 (High Counci of Justice (2017)); Report first reading, above n. 12, at 3 and 53; Leestmans, above n. 2, at 10-11; Traest (2013), above n. 3, at 403; Traest a.o. (2019), above n. 2, at 487

25. Explanatory memorandum, above n. 22, at 12-13.

26. High Council of Justice (2017), above n. 24, at 6; Traest a.o. (2019), above n. 2, at 487.

27. The 'Hoge Raad voor de Justitie', 'Conseil supérieur de la Justice' (High Council of Justice) is an authority that intends the Belgian justice system to operate better. It is involved in the selection and appointment of judges and handles investigations and complaints relating to the functioning of the justice system. It also makes recommendations and gives opinions (Art. 151 Belgian Constitution). See www.csj.be/en.

28. The Belgian CCP also provides the possibility to reopen a criminal case after a conviction by the European Court of Human Rights for a violation of the European Convention for the Protection of Human Rights and Fundamental Freedoms or its additional protocols. This procedure is described in Art. 442bis et seq. Since this procedure is distinct from the procedure for revision, it will not be discussed in this article.

29. Explanatory memorandum, above n. 22, at 10. oncilable, so that one of the convicted persons has to be innocent;

2. after a conviction, a witness that was heard is convicted for false testimony concerning the defendant;

3. an element that was unknown to the judge during the initial proceedings and impossible for the convicted person to demonstrate at that time and that, either alone or combined with the evidence that was gathered before, seems incompatible with the conviction, thus creating a strong suspicion that, if the element had been known, it would have led to an acquittal, a discontinuance of the proceedings or the application of a less strict criminal provision. ${ }^{30}$ This element is also referred to as a novum.

The grounds for revision in Belgium are very similar to the former grounds for revision in France. Yet while the French legislature, in the Act of 2014, decided to maintain only the last ground, arguing that the other grounds for revision are included in that ground, ${ }^{31}$ the Belgian legislature decided to maintain the three separate grounds. ${ }^{32}$ Depending on the ground a request for revision invokes, the procedure for examining the request is different (Art. 445 CCP). For example, in regard to the first or second ground for revision, no advice will be given by the Commission for revision in criminal matters (see infra). Moreover, a request based on the second ground, a false testimony, has to be filed within five years since the final conviction for false testimony, while for the other grounds for revision there is no time limit (Art. 443 CCP).

The grounds for revision are similar not only to the former French grounds, but also to some of the current Dutch grounds for revision. Especially the third ground for revision, the novum, shows a strong resemblance since its modification in 2018. Before 2018, the third ground for revision in Belgium spoke of a new fact or a circumstance that the convicted person could not possibly demonstrate at the time of the initial proceedings and that seemed to demonstrate the convicted person's innocence or the application of a more strict criminal

30. Art. $443,3^{\circ} \mathrm{CCP}$ : 'Wanneer er sprake is van een gegeven dat bij het onderzoek op de terechtzitting aan de rechter niet bekend was en waarvan de veroordeelde het bestaan niet heeft kunnen aantonen ten tijde van het geding en dat, op zichzelf of in verband met de vroeger geleverde bewijzen, met de uitspraak niet bestaanbaar schijnt, zodanig dat het ernstige vermoeden ontstaat dat indien dit gegeven bekend zou zijn geweest, het onderzoek van de zaak zou hebben geleid, hetzij tot een vrijspraak van de veroordeelde, hetzij tot het verval van de strafvordering, hetzij tot het ontslag van rechtsvervolging, hetzij tot de toepassing van een minder strenge strafwet.' - 'Si un élément qui n'était pas connu du juge au moment de l'instruction faite à l'audience et que le condamné n'a pas été à même d'établir lors du procès et que cet élément, en lui-même ou conjugué aux preuves qui avaient été fournies, paraît incompatible avec le jugement, de manière à faire naître une présomption grave que si cet élément avait été connu, l'instruction de l'affaire aurait donné lieu soit à un acquittement du condamné, soit à l'extinction de l'action publique, soit à l'absolution, soit à l'application d'une loi pénale moins sévère.'

31. Rapport $n^{\circ} 467$ enregistré le 16 avril 2014 sur la proposition de loi, adoptée par l'Assemblée nationale, relative à la réforme des procédures de révision et de réexamen d'une condamnation pénale définitive par M. Nicolas Alfonsi, Sénat 2013-14, at 5, 21 and 40.

32. Explanatory memorandum, above n. 22, at 11-2. 
provision than the one he had violated in reality (former Art. 443 CCP). This ground thus concerned new or unknown factual elements. Examples are newly discovered files, ${ }^{33}$ a confession by the actual perpetrator ${ }^{34}$ and a new testimony of a witness or accomplice on the condition that it seems genuine. ${ }^{35}$ By contrast, new discussions or appreciations of facts that were already known were not considered a new fact or an unknown circumstance that the convicted person could not possibly demonstrate. ${ }^{36}$ This entailed that a new conclusion of an expert was considered a possible ground for revision only if the conclusion was based on new scientific techniques. ${ }^{37}$ If the different conclusion was not based on a new scientific technique, it was no new fact, but a new appreciation of facts that were already known and could therefore not be successfully invoked in a request for revision. ${ }^{38}$ The third ground for revision was severely criticised for this narrow scope. ${ }^{39}$

The legislature in 2018 took note of this criticism and wanted to include in the third ground new appreciations by or conclusions of experts who did not make use of new scientific techniques. ${ }^{40}$ It therefore replaced the third ground for revision by the Act of 2018 and introduced the concept of 'an element'. This wording was strongly inspired by the Dutch legislation, as was recommended by the High Council of Justice in 2016. ${ }^{41}$ However, it is not yet clear how much this ground for revision has actually broadened. In the parliamentary debate, it became clear that the legislature did not want to limit it to factual circumstances, but favoured the inclusion of changed appreciations by experts. ${ }^{42}$ It remains unclear, however, whether the expansion is limited to those appreciations by experts or goes further, to include other types of new insights on known facts as well, ${ }^{43}$ a question for the Court of Cassation to resolve.

\subsection{Examination of the Request}

\subsubsection{Admissibility and More: Court of Cassation}

The applicant has to file the request for revision at the Court of Cassation. In order to be admissible, some con-

33. Court of Cassation 5 June 1996, P.96.0310.F

34. Court of Cassation 14 September 1982, 7280.

35. Court of Cassation 12 November 1986, 5251; Court of Cassation 1 March 1995, P.94.1025.F; Court of Cassation 22 September 1999, P. 99.1089.F; Court of Cassation 18 October 2000, P.00.0880.F.

36. M. Meysman and A. Bailleux, 'Nota wetsontwerp houdende diverse bepalingen in strafzaken', Orde van Vlaamse Balies Working Paper 2018, at 1-2 (hereinafter: OVB Working Paper).

37. Court of Cassation 25 April 1996, P.95.1490.N.

38. Explanatory memorandum, above n. 22, at 11; OVB Working Paper, above n. 36, at 1-2.

39. Traest (2013), above n. 3, at 404

40. Explanatory memorandum, above n. 22, at 11

41. Hoge Raad voor de Justitie - Conseil supérieur de la Justice, 'Advies herziening in strafzaken' - 'Avis révision en matière pénale', Working Paper 2016, at 7 (hereinafter: High Council of Justice (2016)); Explanatory memorandum, above n. 22, at 11.

42. Explanatory memorandum, above n. 22, at 11; Traest a.o. (2019), above n. 2, at 486.

43. OVB Working Paper, above n. 36, at 3; K. Verhesschen and F. Verbruggen, 'Niets dan de waarheid? Grenzen aan de waarheidsvinding in het strafrecht', in F. Fleerackers and R. Van Ransbeeck (eds.), Recht en Waarheid (2020) 93, at 112 (hereinafter: Verhesschen a.o.). ditions have to be met. First, if the request is filed by the convicted person or one of his aforementioned relatives, the request has to be signed by a lawyer (Art. 444 CCP) (see supra). Moreover, the request has to be accompanied by the favourable opinion of three other lawyers, who are either registered at the Bar of Lawyers at the Court of Cassation or have been registered at the 'ordinary' bar for at least ten years (Art. 443 CCP). Both requirements are intended to exclude requests that clearly have no prospect of success. ${ }^{44}$ In addition, the request has to contain an elaborate account of the facts and state the ground for revision on which it is based. It also has to add pieces that demonstrate the ground for revision (Art. 444 CCP). If, in the initial proceedings, a civil party was involved, the applicant has to notify the civil party of his request for revision; otherwise, his request will also be inadmissible. ${ }^{45}$

The requirement to add pieces that demonstrate the ground for revision is one of the novelties of the Act of 2018. The legislature wanted to ensure that the Court of Cassation can easily filter out requests that are manifestly unfounded. ${ }^{46}$ When the request is based on one of the first two grounds for revision (incompatible convictions or a conviction for false testimony), this requirement will not present such a high hurdle. ${ }^{47}$ As concerns the first ground, it will probably be sufficient to add the conflicting conviction. If the Court of Cassation then finds that the convictions are indeed incompatible so that one of the convicted persons has to be innocent, it nullifies both convictions. As concerns the second ground for revision, adding the conviction of the witness for false testimony will probably be sufficient. If the Court of Cassation then finds that that conviction indeed concerns a witness that was heard in the initial proceedings, it nullifies the original conviction. In both cases, the Court of Cassation then refers the matter to a court of appeal or assize court ${ }^{48}$ other than the one that had rendered the original conviction(s), regardless of the possible prescription of the criminal proceedings ${ }^{49}$ or the death of the defendant (Art. 445 CCP). That court of appeal or assize court will then render a new decision on the merits. It can acquit the applicant, impose a more lenient penalty or confirm the original conviction. It cannot, by contrast, impose a more severe penalty (Art. 447 CCP). ${ }^{50}$

Yet for applicants who base their request on the third ground, the novum, the requirement to add pieces that demonstrate the ground for revision might present a

Mahieu a.o., above n. 9, at 101-2; Traest (2013), above n. 3, at 388-9.

45. Court of Cassation 23 February 2016, P.15.1586.N; Mahieu a.o., above n. 9, at 104; Traest (2013), above n. 3, at 389; Traest a.o. (2019), above n. 2, at 489 .

46. Explanatory memorandum, above n. 22, at 13

47. Traest a.o. (2019), above n. 2, at 489.

48. A 'hof van assisen', 'cour d'assises' (assize court) is a court that judges the most serious crimes, such as murder and manslaughter, and is characterised by the involvement of a lay jury and the oral character of its proceedings (Art. 280 and 287 CCP).

49. Mahieu a.o., above n. 9 , at 118 .

50. Traest a.o. (2019), above n. 2, at 490. 
much higher hurdle. ${ }^{51}$ Those pieces have to create a 'strong suspicion' that the element they demonstrate would have led to a different outcome if it had been known at the initial proceedings. It is unclear what type of pieces and how many would then be sufficient. It is important to note that, contrary to the procedure in, for example, France ${ }^{52}$ and the Netherlands ${ }^{53}$, the applicant under Belgian legislation has no formal possibility to ask investigative measures before filing his request for revision. Yet he is expected to put forward the right pieces when filing this request, or else it will be filtered out immediately. Depending on how strictly the Court of Cassation will interpret this requirement, the hurdle might thus be very or even too high for many applicants. $^{54}$

If the request for revision is based on the third ground, the novum, and is not inadmissible, the Court of Cassation proceeds to examine whether there are sufficient indications that there might be a ground for revision. ${ }^{55}$ If there are none, it dismisses the request as manifestly unfounded. But if such indications are indeed present, it refers the request for advice to the 'Commissie voor herziening in strafzaken', 'Commission de révision en matière pénale' (Commission for revision in criminal matters; hereinafter also: Commission) (Art. 445 CCP). That Commission will examine whether a novum is indeed present (see infra). ${ }^{56}$

\subsubsection{Presence of a Novum: Commission for Revision in Criminal Matters}

a) Composition of the Commission

The creation of the Commission for revision in criminal matters is another important novelty of the Act of 2018. Earlier, the Court of Cassation referred the request for advice to a court of appeal, which then had to examine whether the facts and circumstances invoked in the request 'seemed sufficiently decisive' to revise the matter (former Art. 445 CCP). If legitimately given, its

51. Traest a.o. (2019), above n. 2, at 489 and 495; Verhesschen a.o., above n. 43 , at 113.

52. In France, according to Art. 626 of the 'Code de procédure pénale', when preparing a request for revision, the applicant has the possibility to ask the public prosecutor to carry out the investigative measures that seem necessary to bring to light a new fact or an element that was unknown at the time of the initial proceedings. For more information, see K. Verhesschen and C. Fijnaut, 'Correcting Wrongful Convictions in France: Has the Act of 2014 Opened the Door to Revision?', also in this issue of Erasmus Law Review.

53. In the Netherlands, Art. 461 et seq. of the 'Wetboek van Strafvordering' provide the possibility for a person convicted for an offence for which the Criminal Code lays down a penalty of 12 years' imprisonment or more and that severely shocked the legal order to request the attorney general via his lawyer to investigate whether a ground for revision is present. Apart from the formal procedure provided in the 'Wetboek van Strafvordering', there are also private initiatives to investigate the possibility of a wrongful conviction, such as the project 'Gerede Twijfel' at the Vrije Universiteit Amsterdam and the project 'Dubieuze zaken' at Maastricht University.

54. Report first reading, above n. 12, at 17; OVB Working Paper, above $n$. 36 , at 2; Verhesschen a.o., above n. 43, at 113.

55. Explanatory memorandum, above n. 22, at 13-14.

56. Explanatory memorandum, above n. 22, at 10 and 14; Traest a.o. (2019), above n. 2, at 495 advice was binding for the Court of Cassation. ${ }^{57}$ This part of the procedure was severely criticised for two reasons. First, only judges were involved in the examination of a request for revision. ${ }^{58}$ Second, the court of appeal to which the Court of Cassation referred the request for advice could be the same court as the one that had rendered the original conviction. ${ }^{59}$ Although the conviction was rendered by the criminal chamber, while the advice on the request for revision was delivered by the civil chamber, this created an appearance of prejudice. ${ }^{60}$

The legislature was strongly aware of these negative appearances and created the Commission for revision in criminal matters to counter them. This Commission is a permanent, independent body ${ }^{61}$ and is composed of a judge, a member of the public prosecutor's office, two lawyers and a member that is appointed on the basis of his expertise or experience related to the tasks delegated to the Commission (Art. 445 CCP). All members are appointed for five years, and their appointment is renewable. ${ }^{62}$ This multidisciplinary composition ensures that a request for revision is not examined by judges alone. Moreover, once appointed, the Commission has to draft its internal rules, containing a procedure on the exemption of a member whose independence or impartiality might be dubious. ${ }^{63}$ This way, the legislature wanted to eradicate all appearances of partiality and prejudice. ${ }^{64}$ One can question, however, whether the Commission is truly independent, since it interferes in the revision procedure only after the Court of Cassation has filtered out the inadmissible and manifestly unfounded requests (see supra). ${ }^{65}$ Yet the Commission is called an independent body because it is intended to be independent in its task of advising on the presence of a novum, as is demonstrated by its composition (see supra) and the requirement to publish its advice (see infra).

Since Belgium is a multilingual state, there will, in fact, be two Commissions for revision in criminal matters, one that is Dutch speaking and the other French speak-

57. Mahieu a.o., above n. 9, at 113-14; Traest (2013), above n. 3, at 391-3.

58. High Council of Justice (2016), above n. 41, at 9; Explanatory memorandum, above n. 22, at 6-7; Traest a.o. (2019), above n. 2, at 496.

59. As happened in the case of Mr Meert (see supra footnote 1).

60. High Council of Justice (2016), above n. 41, at 9; Explanatory memorandum, above n. 22, at 6-7; Colette, above n. 3, at 13; Traest (2013), above n. 3, at 391; Traest a.o. (2019), above n. 2, at 496.

61. Explanatory memorandum, above n. 22, at 7; Report first reading, above n. 12, at 25 and 55.

62. Art. 2 Koninklijk Besluit 19 december 2018 tot vaststelling van de regels inzake de aanstelling van de leden van de Commissie voor de herziening in strafzaken, in uitvoering van artikel 445 van het Wetboek van Strafvordering - Arrêté royal 19 décembre 2018 fixant les règles relatives à la désignation des membres de la Commission de révision en matière pénale, en exécution de l'article 445 du Code d'instruction criminelle, Belgisch Staatsblad - Moniteur belge 24 December 2018, 102202 (hereinafter: Royal decree 19 December 2018).

63. Art. 3 Royal decree 19 December 2018, above n. 62.

64. Explanatory memorandum, above n. 22, at 7 and 14

65. As was questioned by Mr Dennis Martinsson, who provided us with valuable feedback on our article, for which we are very grateful. 
ing. ${ }^{66}$ Both Commissions are separate and will draft their own internal rules, ${ }^{67}$ so it remains to be seen whether they will have a similar or different approach concerning their task and competences.

The creation of the Commission was inspired by the Dutch procedure for revision, which involves the 'Adviescommissie Afgesloten Strafzaken'. ${ }^{68}$ However, the actual implementation of this idea in the Belgian procedure resulted in some differences, for example in its composition and the stage of the procedure at which it interferes. ${ }^{69}$

b) Advice on the presence of a novum

The Commission has to advise on the presence of a novum, so whether the invoked element, alone or combined with the evidence that was gathered before, seems incompatible with the original conviction, thus creating a strong suspicion that it would have led to a different outcome if it had been known at the initial proceedings. ${ }^{70}$ To fulfil its task, the Commission has been given some investigating powers (Art. 445 CCP). ${ }^{71}$ First, it can hear persons who were involved in the initial investigation as well as experts. These include the convicted person, civil party, investigating judge, public prosecutor, members of the police, experts that were involved in the initial proceedings and also other experts. ${ }^{72}$ Yet it does not seem to oblige the Commission to hear the applicant, it only facilitates it. ${ }^{73}$ Moreover, some authors $^{74}$ question whether this competence, in view of its wording, also includes the possibility for the Commission to hear witnesses that were heard in the initial proceedings. ${ }^{75}$ The application of this provision in prac-

66. Because of this multilingual character, in Belgium, judges are assigned to a Dutch or a French linguistic register. Moreover, there are two bar associations, one for the Flemish (Dutch speaking) lawyers (Orde van Vlaamse Balies) and one for the French- and German-speaking lawyers (Ordre des Barreaux Francophones et Germanophone de Belgique). For those reasons, there will be a Dutch-speaking and a French-speaking Commission for revision in criminal matters. The Dutch-speaking Commission has been formed only recently, the ministerial order appointing the final member was published in the Official State's Gazette (Belgisch Staatsblad, Moniteur belge) on 4 May 2020. By contrast, on the French-speaking Commission, no information had been published at the time of writing this article (finalised in August 2020). However, in the period between the submission and the publication of this article, the ministerial order appointing the judge, the member of the public prosecutor's office and the two lawyers for the French-speaking Commission was published in the Official State's Gazette on 8 January 2021. The expert member has not been appointed yet.

67. Art. 3 Royal decree 19 December 2018, above n. 62

68. High Council of Justice (2016), above n. 41, at 9-10.

69. For a comparison, see C. Fijnaut and K. Verhesschen, 'Minder juristen, meer andere deskundigen bij de herziening van de herziening in Nederland en België?', 6 Expertise en Recht 269 (2018) (hereinafter: Fijnaut a.o.).

70. Traest a.o. (2019), above n. 2, at 498.

71. Explanatory memorandum, above n. 22, at 15.

72. Traest a.o. (2019), above n. 2, at 499.

73. Report first reading, above n. 12, at 56

74. Traest a.o. (2019), above n. 2, at 499.

75. The Dutch version states 'personen die bij het onderzoek in de zaak betrokken waren', the French version 'I'audition de personnes impliquées dans l'instruction', so it is open for discussion whether those witnesses are covered by this provision. Its wording does not necessarily seem to exclude them. tice will have to clarify this, ${ }^{76}$ but hearing the witnesses from the initial proceedings seems an indispensable competence for the Commission in order to properly examine the presence of a novum. However, if the Commission would be unable to hear those witnesses on its own initiative, it might make use of its competence to request investigative measures at the Court of Cassation (see infra) to get (transcripts of) a hearing of those witnesses.

Second, in addition to the expert that is a permanent member of the Commission, the Commission can appoint an expert in light of the scientific or technical expertise needed to examine the request at hand. ${ }^{77}$

Third, the Commission can request investigative measures at the Court of Cassation. It has to indicate what measures are required and why. ${ }^{78}$ The Court of Cassation will then decide whether they are indeed necessary and thus have to be performed. If it decides that they are, the investigative measures are carried out by a public prosecutor's office that was not involved in the initial investigation. ${ }^{79}$ Otherwise, the Court of Cassation will have to motivate its decision not to comply with the request of the Commission. The Court of Cassation can also decide on its own account that investigative measures are required. ${ }^{80}$

Some authors raise the question of whether the Commission can ask for all types of investigative measures. ${ }^{81}$ In Belgium, depending on how far-reaching an investigative measure is, a prior authorisation of an investigating judge is needed. ${ }^{82}$ Yet the provisions on the revision procedure remain silent on how this prior judicial control has to be applied in the context of this procedure, so it is not clear whether such measures can be asked for. ${ }^{83}$ This is another question for practice to resolve. However, for the restoration of people's confidence in the justice system, the credibility of the Commission is crucial, and that credibility is, in its turn, linked to the

76. Or the internal rules of the Commission, which have to contain provisions on the possibility to hear persons involved in the initial investigation and experts (Art. 3 Royal decree 19 December 2018, above n. 62).

77. Explanatory memorandum, above n. 22, at 9.

78. Explanatory memorandum, above n. 22, at 15; Traest a.o. (2019), above n. 2, at 501.

79. Explanatory memorandum, above n. 22, at 15

80. Explanatory memorandum, above n. 22, at 15; Traest a.o. (2019), above n. 2, at 505.

81. Traest a.o. (2019), above n. 2, at 502-5

82. For example when a house search, DNA test without the permission of the person involved, telephone bug or arrest warrant is needed. In Belgium, there is a distinction between the 'opsporingsonderzoek', 'information' (preliminary investigation), which is directed by a public prosecutor and the 'gerechtelijk onderzoek', 'instruction' (judicial investigation), which is directed by an investigating judge. In principle, the more invasive investigative measures are possible only in a judicial investigation. Yet the list of exceptions to this principle is constantly growing, making the distinction between the two types of investigations more and more contested. In the blueprints for a new criminal procedure, the distinction is therefore abolished: each investigation is directed by a public prosecutor, and the investigating judge will intervene in the investigation for specific authorisations (R. Verstraeten and A. Bailleux, 'Het voorstel van een nieuw Wetboek van Strafvordering: algemene beginselen en fase van het onderzoek', 110 Themis Straf- en strafprocesrecht 143, at 146 (2019)).

83. Traest a.o. (2019), above n. 2, at 502-5. 
means the Commission has to thoroughly examine requests for revision. Therefore, a thorough debate and clearer legal provisions on the investigative measures that can be requested by the Commission and ordered by the Court of Cassation in the context of the revision procedure would have been welcome.

The Commission thus has to assess whether the invoked element, either alone or combined with the evidence that was gathered before, seems incompatible with the original conviction. The Commission may involve all information from the criminal file that had been subject to the (possibility of) contradiction by the parties. ${ }^{84}$ This requires that evidence is still available at the time of the request for revision. Unfortunately, there is no clear, global regulation ${ }^{85}$ on the storage of evidence in Belgium. ${ }^{86}$

After its examination, the Commission advises the Court of Cassation on the presence of a novum. Its advice will be made public after the Court of Cassation rendered the final decision on the request for revision (Art. 445 CCP). This is another guarantee for the Commission's independence. ${ }^{87}$ Moreover, it enhances the transparency of the procedure, which might contribute to the public's confidence in the justice system. ${ }^{88}$ To avoid an illegal interference in the independence of the judiciary, the advice of the Commission does not bind the Court of Cassation. ${ }^{89}$

\subsubsection{Referral or Not: Court of Cassation}

Once the Commission for revision in criminal matters has rendered its advice, the request for revision returns to the Court of Cassation (Art. 445 CCP). As mentioned previously, the Court is not bound by the advice. However, if it decides not to comply with it, it will have to motivate that decision. ${ }^{90}$

The Court of Cassation decides in a public hearing, at which the parties can be present. ${ }^{91}$ However, it is not clear yet whether they will be able to take note of the Commission's advice before the hearing of the Court of Cassation is held. The Act of 2018 does not specify whether they will be notified of the advice and given time to prepare their remarks, nor does the Royal Decree of 19 December 2018. ${ }^{92}$ To ensure a contradictory debate, the advice will have to be added to the criminal file before the hearing of the Court of Cassation, but it is regrettable that the Act does not explicitly

84. Traest a.o. (2019), above n. 2, at 495-6.

85. There are separate rules on, for example, the confiscation of seized assets and the management of such assets, and on the storage of DNA samples.

86. S. Royer, Strafrechtelijk beslag: digiproof en (multi)funtioneel (2020), at 56.

87. Explanatory memorandum, above n. 22, at 14

88. Verhesschen a.o., above n. 43, at 115.

89. Explanatory memorandum, above n. 22, at 14

90. Explanatory memorandum, above n. 22, at 14

91. Traest a.o. (2019), above n. 2, at 507.

92. Report first reading, above n. 12, at 56; Verhesschen a.o., above n. 43 , at 115 . stipulate this, nor the time given to the applicant after the notification of the advice to prepare his remarks. ${ }^{93}$

The Court of Cassation renders a final decision on the presence of a novum and thus on whether or not to allow a revision. If it finds that the conditions for the third ground for revision are not fulfilled, it dismisses the request. If it finds that they are, it nullifies the original conviction and refers the case to a court of appeal or assize court other than the one that had rendered the original conviction for a new decision on the merits of the case (Art. 445 CCP) (see supra).

\section{Practice and Challenges Concerning the Revision Procedure}

There are no official annual statistics available on the application of the former revision procedure. Only in responses to parliamentary questions, the number of applications in a specific year or time frame can be found. For example, between 2000 and 14 July 2015, decisions were taken on fifty requests for revision, and in ten of these cases the original conviction was nullified. ${ }^{94}$ The lack of annual data on the application of the revision procedure will make it harder to assess the impact of the recent reform on the accessibility of the procedure.

However, currently, it is not only the lack of data on the former procedure that makes it difficult to assess the actual impact of the reform. As previously clarified, the legal framework of the new revision procedure leaves a lot of questions unanswered. The application in practice will have to clarify the scope of the third ground for revision (the novum), the magnitude of the various hurdles to the actual revision, the investigating powers of the Commission for revision in criminal matters, the possibility of a contradictory debate about the advice of the Commission, etc. Unfortunately, there is little practice to turn to yet, since the final member of the Dutchspeaking Commission for revision in criminal matters was appointed as recently as 17 April 2020, published in the Official State's Gazette on 4 May 2020, and so far, no information has been published on the Frenchspeaking Commission (see supra). ${ }^{95}$ It thus took over a year after its entry into force ${ }^{96}$ to implement all aspects of the Act of 2018.

93. Traest a.o. (2019), above n. 2, at 507; Verhesschen a.o., above n. 43 at 115 .

94. Vragen en antwoorden Kamer (Commissie voor de Justitie), n. 16761, 22 februari 2017 - Questions et réponses Chambre (Commission de la Justice), n. 16761, 22 février 2017.

95. No information had been published yet at the time of writing this article, which was finalised in August 2020. However, in the period between the submission and the publication of this article, on 8 January 2021, the ministerial order appointing four members of the Frenchspeaking Commission was published in the Official State's Gazette (see supra footnote 66).

96. Which was on 1 March 2019 (above n. 7). 
It is striking how long it took to form the Commission for revision in criminal matters. The first call for candidates was published in the Official State's Gazette as early as on 10 January 2019. However, as it was difficult to find a judge (for the French-speaking Commission) and a member of the public prosecutor's office (for both Commissions), a new call for these members was published, on 26 April 2019. ${ }^{97}$ This might be an indication of the sensitivity of this procedure and the possible distrust towards the newly established Commission.

The Commission for revision in criminal matters thus has the difficult task to, on the one hand, dispel the distrust of the judiciary and, on the other hand, restore people's confidence in the justice system. For those reasons, it is crucial that the Commission can thoroughly examine a request for revision and gives a motivated advice, and that it is made public. It is therefore very welcome that Article 445 CCP explicitly states that the advice of the Commission will be made public after the Court of Cassation has rendered the final decision on the request for revision. ${ }^{98}$ Only by this means can the procedure stand up to scrutiny and gain or restore the confidence of both the judiciary and society. ${ }^{99}$ Unfortunately, the Act of 2018 does not contain an explicit obligation for the Commission to motivate its advice. However, to properly advise the Court of Cassation, it will have to state the main reasons. ${ }^{100}$

It is remarkable that although its task is to examine the presence of a novum, the composition of the Commission allows ${ }^{101}$ for only one member to have a non-legal background. ${ }^{102}$ The Commission thus has little access to in-house scientific or technical expertise. However, to counter this, if more expertise is needed, it can appoint an expert in light of the request at hand.

Not only the Commission for revision in criminal matters, but also the Court of Cassation has an important role to play in restoring people's confidence in the justice system. It is the Court of Cassation that decides on the admissibility of a request and that examines whether there are sufficient indications that a ground for revision might exist, before sending the request to the Commission (see supra). It thus serves as a first filter. Although it seemed like the legislature wanted to widen the possibility to obtain a revision by broadening the definition of a novum, it also introduced the requirement for the applicant to add pieces that demonstrate the ground for revision. As explained earlier, if the request for revision is based on a novum, adding those pieces might be a dif- ficult requirement for most applicants. ${ }^{103}$ Depending on how strictly the Court of Cassation will perform its task as a first filter, it might thus make the procedure less accessible again. ${ }^{104}$

Moreover, the Court of Cassation renders the final decision on the request for revision. It decides whether or not to refer the case to a court of appeal or an assize court for a new decision on the merits (Art. 445 CCP) (see supra). As the preparatory works make clear, the Court will have to motivate its decision if it decides not to comply with the advice of the Commission. ${ }^{105}$ This as well might enhance the transparency of the decisionmaking and thus contribute to the restoration of people's confidence in the justice system.

\section{Conclusion}

The Act of 2018 responded to several of the criticisms voiced by legal doctrine, but not to all. Convictions imposing a police penalty are still excluded from the scope of the revision procedure (Art. 443 CCP). However, such convictions are becoming increasingly rare. ${ }^{106}$ It did respond to the criticism that the scope of the third ground for revision, the novum, was too narrow. It broadened its wording to include changed appreciations by or conclusions of experts who did not make use of new scientific techniques. However, it is unclear whether the newly formulated novum also includes other types of new insights on known facts as well.

The former procedure for revision was also severely criticised because it involved only judges in the examination of a request for revision. Moreover, when the Court of Cassation had to send the request to a court of appeal for advice on the invoked facts and circumstances, it could send it to (the civil chamber of) the court of appeal that had rendered the original conviction. This created appearances of partiality and prejudice. The Act of 2018 responded to this criticism by creating the Commission for revision in criminal matters, a multidisciplinary and independent body that provides non-binding advice to the Court of Cassation on the presence of a novum. Thereby, the Act of 2018 ensures that the request for revision is not examined by judges alone and also guards the independence of the judiciary by stating that the advice of the Commission is non-binding.
97. According to Art. 81 of the Act of 2018 , by then, the new revision procedure had already entered into force.

98. Note that neither the Act of 2018 nor the Royal decree of 19 December 2018 clarifies how the advice will be made public. All possible means are allowed, so they will probably be published on a webpage (Traest a.o. (2019), above n. 2, at 507).

99. Fijnaut a.o., above n. 69, at 274; Verhesschen a.o., above n. 43, at 115

100. Traest a.o. (2019), above n. 2, at 506.

101. It allows it, but does not oblige it. It is thus not required that the member of the Commission who is appointed based on his expertise or experience has a non-legal background. For example, academics practising legal research are also eligible.

102. Fijnaut a.o., above n. 69, at 274.
103. Report first reading, above n. 12, at 17; OVB Working Paper, above $n$. 36, at 2; Verhesschen a.o., above n. 43, at 113.

104. Fijnaut a.o., above n. 69, at 275 .

105. Explanatory memorandum, above n. 22, at 14.

106. Moreover, in the proposal for a new 'Strafwetboek', 'Code pénal', the category of 'overtredingen', 'contraventions' is abolished, so there would no longer be convictions imposing police penalties (J. Rozie, D. Vandermeersch, J. De Herdt, M. Debauche \& M. Taeymans, Commissie voor de Hervorming van het Strafrecht. Voorstel van voorontwerp van Boek I van het Strafwetboek (2017), at 39). 
In general, the Act of 2018 was warmly welcomed and positively received. ${ }^{107}$ Compared with the previous procedure, it is a huge step forward.

However, the proof of the pudding is in the eating. An improved legal framework in itself is insufficient to restore people's confidence in the justice system. Moreover, the Act of 2018 leaves many questions unanswered. Its application in practice will have to clarify how strictly the Court of Cassation will interpret the requirement to add pieces to a request for revision and how it will play its role as a first filter. It will then become clear whether in reality the Act of 2018 made the revision procedure more accessible or not. Moreover, time will tell whether the Commission for revision in criminal matters has the means to thoroughly examine requests for revision and will elaborately motivate its advice. Whether the reform of 2018 will help restore people's confidence in the justice system thus hinges on the way in which the different actors involved apply those legal provisions.

Nevertheless, to ensure people have confidence in the justice system, a well-functioning revision procedure is not enough. Also of considerable importance is that wrongful convictions be prevented as much as possible. At each stage of the criminal procedure, sufficient safeguards should be in place, and all actors should be aware of the possibility of mistakes and of the various pitfalls and possible abuses and try to counter them. 